\title{
EFFECTS OF DROUGHT STRESS ON SEED SINK STRENGTH AND LEAF PROTEIN PATTERNS OF COMMON BEAN GENOTYPES
}

\author{
SETEGN GEBEYEHU ${ }^{1,2}$, HEIKE WIESE ${ }^{1}$ and SVEN SCHUBERT ${ }^{1}$ \\ ${ }^{1}$ Institut für Pflanzenernährung, Justus-Liebig-Universität Giessen, Heinrich-Buff-Ring 26-32 \\ D-35392 Giessen, Germany \\ ${ }^{2}$ Current Addresses: National Bean Research Project, Melkassa Agricultural Research Center, \\ P. O. Box 436, Adama, Ethiopia \\ Corresponding author: setegng@yahoo.co.uk
}

(Received 7 January, 2010; accepted 26 May, 2010)

\begin{abstract}
Assimilate availability and the capacity to utilise them in the reproductive structures to a large extent determine reproductive sink establishment and yield of crops under drought stress. This study was carried out to investigate the effect of drought stress imposed at early pod-fill stage on seed sink strength of common bean (Phaseolus vulgaris L.) genotypes differing in drought resistance. Quantitative and qualitative changes in leaf protein patterns was assessed using 2D-gel electrophoresis. A drought-resistant inbred line (SEA 15) and a droughtsusceptible cultivar (BrSp) were grown under non-stress and drought stress conditions in a vegetation hall during the summer of 2004. Drought stress commenced at early pod-filling stage caused 53 and $30 \%$ seed yield reductions in BrSp and SEA 15, respectively. The effect of drought on seed yield was primarily due to the significant reduction in number of seeds per plant (48\% for BrSp vs. 35\% for SEA 15). Whereas seed sucrose concentrations of BrSp decreased by 29 to $47 \%$ under drought conditions, the stress resulted in an increase (up to $43 \%$ ) in concentration of the carbohydrate in SEA 15 seeds. Despite the genotypic difference found for seed sucrose import, seed starch accumulations of the two genotypes decreased under drought stress. For both genotypes, none of the seed sink capacity parameters (numbers and volumes of cotyledonary cells and starch granules per seed) were significantly affected by the stress imposed implying that the drought-induced decrease in seed starch accumulation could be due to limitations in assimilate availability and/or other sink activity factors within the seed. A total of 230 leaf proteins were differentially expressed due to drought out of which 23.5, 15.1, 4.3 and $3.5 \%$ were down-regulated, up-regulated, newly appeared and disappeared, respectively. Identification and assigning possible functions in the crop's response to drought of the stress-induced proteins warrant further study.
\end{abstract}

Key Words: Assimilate, drought resistance, Phaseolus vulgaris

\section{RÉSUMÉ}

La disponibilité des assimilats et la capacité de les utiliser dans des structures reproductrices, déterminent en grande partie l'établissement du "sink" reproducteur et les rendements des cultures en conditions de secheresse. Cette étude avait pour objectif l'étude de l'effet du stress hydrique imposé au stade du remplissage des gousses, sur la consistence du "sink" de graines de génotypes du haricot commun (Phaseolus vulgaris L.) de différente résistance à la secheresse. Des changements quantitatfs et qualitatifs dans les structures de protéine des feuilles étaient évalués par l'électrophorèse 2D-gel.Une souche pure résistante à la sécheresse (MER 15) et un cultivar non résistant à la sécheresse (BrSp) étaient cultivés à la fois en conditions de stess et sans stress hydrique dans un hall de vegetation au cours de l'été 2004. Le stress hydrique imposé tôt au stade de remplissage de gousses a entrainé une réduction de rendement en grains de 53 à 30\% dans BrSp et SEA 15, respectivement. L'effet du stress hydrique sur le rendement en grains était principalement dû à la réduction significative du nombre de grains 
par plant (48\% pour BrSp contre 35\% pour SEA 15).Alors que les concentrations en sucrose dans les grains de BrSp avaient décru de 29 à $47 \%$ en conditions de sécheresse, la concentration en hydrates de carbone a augmenté jusqu'à $43 \%$ dans les grains de SEA 15. Malgré la différence génotypique trouvée pour l'importation du sucrose dans la graine, l'accumulation de l'amidon dans la graine de deux genotypes a décru en conditions de sécheresse. Pour les deux genotypes,aucun des paramètres de la capacité du sink du grain (nombres et volumes de cellules de cotyledons et granules d'amidon par grain) étaient significativement affectés par le stess imposé, induisant une réduction dans l'accumulation de l'amidon dans le grain qui serait due à la disponibilité des assimilats et/ou d'autres facteurs de l'activité du sink dans la graine. Au total 230 protéines dans les feuilles étaient exprimées de façon différentielle suite à la sécheresse en dehors de laquelle 23.5, 15.1, 4.3 et 3.5\% étaient respectivement sous régulés, sur-régulés, nouvellement apparus et disparus. L'identification et l'attribution des fonctions possibles des protéines sous tress induit en réponse de la plante à la sécheresse nécessitent une étude supplémentaire.

Mots Clés: Assimilat, résistance à la sécheresse, Phaseolus vulgaris

\section{INTRODUCTION}

As most of common bean (Phaseolus vulgaris L.) production in the developing world occurs under conditions of significant drought stress, average global yield of the crop is estimated at less than $900 \mathrm{~kg} \mathrm{ha}^{-1}$ (Singh, 2001). Reports on drought-induced reduction in seed yield of the crop are highly variable due to differences in the timing and intensity of the stress imposed and the genotypes used (Ramirez-Vallejo and Kelly, 1998). Seed yield-based genotypic differences for drought resistance are frequently reported (Terán and Singh, 2002). The reductions are attributed to adverse effects of the stress on individual yield components.

Drought stress decreases photosynthetic rate, thereby decreasing the amount of assimilates available for export to the sink organs (Kim et al., 2000). Drought can also affect carbohydrate metabolism in plant reproductive organs (Liu et al., 2004). For example, Setter et al. (2001) found higher or at least similar levels of sucrose in maize ovaries between drought-stressed and wellwatered controls. These results imply that, in addition to assimilate availability per se, the capacity for utilising them in the reproductive structures may also be affected under drought stress.

Differences in drought resistance among genotypes of different resistance levels are often related among others to the ability to establish new sink under drought stress (Koç et al., 2003). In line with this, drought stress, when initiated during the reproductive phase, may differentially affect the reproductive sink strength (i.e. capacity to establish new sink) of common bean genotypes differing in drought resistance. Genotypic differences in reproductive sink strength, in turn could, be attributed to the differential effect of drought on the availability and subsequent metabolism of assimilates in the reproductive sink organs.

Drought-induced limitation on seed sink capacities (numbers and volumes of storage organelles) may also differentially hinder seed sink strength leading to reduced accumulation of storage products such as starch and protein. Thus, drought-induced changes in carbohydrate status and metabolism in crop reproductive structures are crucial for successful fruit set. In addition to photosynthate supply, decrease in water potential and higher absisic acid (ABA) accumulation in the reproductive structure of plants subjected to drought may also contribute to the loss of fruit or seed set (Liu et al., 2004).

In addition to the physiological and biochemical responses of plants to water stress, the information on the molecular mechanisms of drought stress adaptation could be useful for the genetic improvement of drought-resistant crops/ genotypes. Proteomics are a recent addition to the molecular tools used to analyse droughtaffected plants (Salekdeh et al., 2002), and have been applied to the study of drought response of several crop plants including barley (NeslihanOzturk et al., 2002) and maize (Riccardi et al., 1998).

Water deficit induces the expression of proteins that are directly or indirectly related to the stress and some functions have been assigned to some of the sequenced proteins 
(Neslihan-Ozturk et al., 2002). Among the stressinduced proteins identified, are those implicated in the biosynthesis of osmolytes (Ishitani et al., 1995), in the uptake and compartmentation of ions (Lisse et al., 1996), in hydroxyl-radical scavenging (Ingram and Bartels, 1996) and protection of cellular structure (Neslihan-Ozturk et al., 2002). Proteins that show significant downregulation under drought stress were observed for photosynthesis-related function (NeslihanOzturk et al., 2002). Changes in protein patterns induced due to drought play a pivotal role in the adaptive response of plants to the stress (Riccardi et al., 1998). In line with these findings, drought stress initiated at different growth stages may induce quantitative and qualitative changes in bean leaf proteins.

The objective of this study was to (i) investigate the differential effect of drought stress on seed sink strength of common bean (Phaseolus vulgaris L.) genotypes differing in degree of drought resistance, and (ii) determine drought-induced quantitative and qualitative changes in leaf protein patterns of the crop.

\section{MATERIALS AND METHODS}

Plant materials. A drought-resistant inbred line (SEA 15) and a susceptible bean cultivar (Brown Speckled hereafter referred as BrSp) were used in this study. The adapted cultivar (BrSp) was chosen among varieties developed by the National Bean Research Programme of Ethiopia for wider adaptations to different agro-ecological conditions of the country. The inbred line (SEA 15) was obtained from the Bean Research Programme of CIAT. Previous studies have demonstrated that the resistant genotype possesses an adequate level of resistance to drought stress under field conditions (CIAT, 2002).

Experimental procedure and design. The two genotypes were grown under non-stress (control) and drought stress initiated at early pod-fill stage during the summer of 2004 at experiment station of the University of Giessen, Germany. Drought stress was imposed by withholding the amount of water applied in order to keep the soil moisture level at about $30 \%$ of the maximum water-holding capacity (WHC). For non-stressed (control) treatments, the soil moisture was maintained at $70 \%$ of the maximum WHC until the plants were harvested.

Seeds of the genotypes were grown in $\mathrm{Ahr}$ pots filled with $13 \mathrm{~kg}$ of Kleinlindener soil. At planting, the soil was fertilised with Blaukorn (12.0\% N, 5.2\% P, 14.1\% K, 1.2\% Mg and 6.0\% S). Eight seeds per pot were initially sown and later thinned to four plants when the first trifoliate leaves were unfolded. Plants were raised in a vegetation hall. The pots were weighed daily and watered to restore the appropriate moisture by adding a calculated amount of water. For both experiments, the treatments were laid in a completely randomised designed with four replications.

Data collection. Data were collected on seed yield per plant, number of productive pods per plant, and number of seeds per pod. Hundred seed weight (HSW) was determined on seeds randomly sampled from all plants harvested per pot. Harvest index (HI) was calculated as the proportion of seed weight to the above-ground plant at harvesting dry weight (stem + leaves + pod + seed) at harvest. Harvested pods were categorised into two groups, namely, productive pods (Pr-P) and aborted pods (Ab-P). The classification of pods was based on length attained and whether or not the pods bore seeds at harvesting. Productive-pods were defined as pods longer than $5 \mathrm{~cm}$ (for the harvest made at 5 d stress), and bore at least one seed per pod (for the harvests made at 10 and $20 \mathrm{~d}$ stress). During the course of pod development, it was observed that the underdeveloped pods (whether dropped off the plant or loosely hanging to the reproductive branches) had less than $5 \mathrm{~cm}$ length. These pods were considered as aborted pods (Ab-P). Also, pods that grew to a length of more than $5 \mathrm{~cm}$ but did not possess typical and healthy seeds (usually found at 10 and $20 \mathrm{~d}$ stress) were regarded as aborted pods.

Chemical analysis. For seed sugar and starch analyses, samples were obtained from the harvests made at 5, 10 and $20 \mathrm{~d}$ after the commencement of drought stress. The various plant parts were dried separately at $80^{\circ} \mathrm{C}$ for $48 \mathrm{~h}$ 
and finely ground materials were used for the chemical analyses.

Sugars: Three-hundred mg ground plant material was weighed into a $50 \mathrm{ml}$ volumetric flask and 30 $\mathrm{ml}$ of double-demineralised water was added. The material was then extracted by incubating in a shaking water bath at $60^{\circ} \mathrm{C}$ for $30 \mathrm{~min}$. The flask was quickly cooled on ice, and filled up to the mark with double-demineralised water followed by filtration with (blue-band) filter paper (Faltenfilter 595 ${ }^{1 / 2}$, Scheicher and Schüll Co., Dassel, Germany). Sugars (sucrose, glucose and fructose) were determined by using enzymatic test kits and absorbances of the solutions were read at $340 \mathrm{~nm}$.

Starch: Starch determination was performed following enzymatic assay procedure using the starch determination kit from Boehringer (Mannheim, Germany). Homogenised ground seed and leaf samples of $300 \mathrm{mg}$ were weighed into Erlenmeyer flasks, and $20 \mathrm{ml}$ of dimethylsulfoxide and $5 \mathrm{ml} \mathrm{HCl}\left(8 \mathrm{~mol} \mathrm{l}^{-1}\right)$ were added. The sealed flask was then incubated for 30 minutes at $60{ }^{\circ} \mathrm{C}$ in a shaking water bath. The sample solutions were cooled quickly to room temperature and approximately $50 \mathrm{ml}$ water was added. The $\mathrm{pH}$ was adjusted to 4-5 with sodium hydroxide (5 M) under vigorous shaking. The solution was then transferred to a $100 \mathrm{ml}$ volumetric flask, rinsed with water, filled up to the mark with water and filtered using Faltenfilter $595^{1 / 2}$ (Scheicher and Schüll Co., Dassel, Germany).

ABA: Metabolite extraction from freeze-dried sink (young fully expanded) leaves of two common bean genotypes were performed following the method used by Wang et al. (2002). Extracts were passed through a Sep Pak C18cartridge. Methanol was removed under reduced pressure and the aqueous residue was partitioned three times against ethyl acetate at $\mathrm{pH}$ 3.0. The ethyl acetate of the combined organic fractions was removed under reduced pressure. The newly obtained residue was taken up in TBS-buffer (Tris buffered saline; $150 \mathrm{mmol} \mathrm{L}^{-1} \mathrm{NaCl} 1 \mathrm{mmol}$ $\mathrm{L}^{-1} \mathrm{MgCl}_{2}$ and $50 \mathrm{mmol} \mathrm{L}^{-1}$ Tris at $\mathrm{pH} 7.8$ ) and subjected to an immunological ABA assay (ELISA) as described earlier (Mertens et al., 1985).

Numbers and sizes of cotyledonary cells and amyloplasts. The number and sizes of cotyledonary cells and amyloplasts were determined on 10 randomly selected seeds per replication obtained from the last harvest (20 d stress). Seed volume was obtained using Archimedes principle (Wessel-Beaver et al., 1984). Dried bean seed weight was determined immediately before measurement of seed volume.

Seeds were softened by soaking in distilled water for one night and then separated into seed coat, cotyledons and embryonic axes. The cotyledons were cut into small pieces, dried at $104{ }^{\circ} \mathrm{C}$ for $24 \mathrm{~h}$, and dry weights determined. The cotyledon samples were then immersed in an enzymatic solution (sorbitol $0.45 \mathrm{M} ; \mathrm{MgCl}_{2} 10$ $\mathrm{mM} ; \mathrm{KH}_{2} \mathrm{PO} 41 \mathrm{mM}$; MES $20 \mathrm{mM}$; Macerozyme ${ }^{\circledR}$ R-10 1\%; pH 5.6) under vacuum conditions for ca. three minutes. The samples were then placed in an oven at $37^{\circ} \mathrm{C}$ for $72 \mathrm{~h}$ and then macerated gently with mortar and pestle.

Macerated cells were separated on a $300 \mu \mathrm{m}$ nylon mesh to obtain a homogeneous $100 \mathrm{ml}$ cotyledonary cell suspension. Parts of the cell suspensions were transferred to a $20 \mathrm{ml}$ tube and vortexed before transferring $2 \mu \mathrm{l}$ aliquots with a micropipette to the middle of a counting grid on a hemacytometer (Medicihaus, Berlin). A cover slip was applied and moved in a circular motion to evenly distribute the cells. Cells were counted under a microscope (Leitz, Wetzlar, Germany) at $25^{\prime}$ magnification, and the counts were taken from the four outer squares of the counting chamber (each $1 \mathrm{~mm}^{2}$ ) for four aliquots for each cell suspension. Computational procedures used for the determinations of numbers and volumes (areas) of cotyledonary cells and amyloplasts are detailed in Gebeyehu et al. (2006).

From the same aliquot used for cell counts, 1 $\mathrm{ml}$ was removed from the suspension and diluted with an equal volume of an iodine solution (3.3 g $\mathrm{l}^{-1} \mathrm{I}_{2}+6.7 \mathrm{~g} \mathrm{l}^{-1} \mathrm{KI}$ ) to stain the starch granules. Stained starch granules (amyloplasts) were counted on a hemacytometer (Medicihaus, Berlin) at 40' magnification. The counts were multiplied by the number of cotyledonary cells to determine 
number of amyloplasts per seed. The same solution used for the determination of number of amyloplasts was used for measuring the size of the granules. Approximately 3 to $5 \mu$ l of the solution was transferred to the middle of a slide on a microscope (LEICA DM IRB, LUDL electronics, NY) equipped with a digital camera (CoolsnapCF, Photometrics). Pictures of 15 to 20 randomly selected cells observed under microscope were visualised on the computer screen and the sizes of 3 to 15 granules per cell with distinct boundaries from the neighbouring amyloplasts were measured using Meta Vue Software (Universal Imaging Corporation). The distance for measurement was calibrated at $40 \mathrm{x}$ magnification $\left(0.11625 \mu \mathrm{m} \mathrm{pixel}{ }^{-1}\right)$.

Proteomic analysis. Proteins were prepared for isoelectric focusing using a DTT-TCA-acetone precipitation method adopted from Zörb et al. (2004). Plants of the genotype BrSp grown under non-stress and drought stress imposed at vegetative growth stage were used for the analysis. Mature leaf material was disrupted by grinding the tissue under liquid nitrogen in a mortar. Ground powder was stored at $-80{ }^{\circ} \mathrm{C}$. Protease activity was inhibited by lowering the temperatures of the cell material $\left(4^{\circ} \mathrm{C}\right)$ and the use of strong denaturants, such as urea and TCA, in the protein sample buffer supplemented by the use of the protease inhibitor Pefablock. Up to 1.6 $\mathrm{ml}$ lysis buffer (10\% TCA in acetone) was added to $3 / 4$-filled ground tissue in a $2 \mathrm{ml}$ Eppendorf tube.

After vortexing, samples were incubated for 15 minutes in an ice-cold ultrasonic bath and incubated at $-20^{\circ} \mathrm{C}$ for $1 \mathrm{~h}$ or overnight before centrifugation $\left(20,000 \mathrm{~g}, 15\right.$ minutes $\left.4^{\circ} \mathrm{C}\right)$. The precipitant was resuspended in $1 \mathrm{ml} 4{ }^{\circ} \mathrm{C}$ cold buffer A (50 mM DTT; 2 mM EDTA, in acetone).

Samples were incubated for $10 \mathrm{~min}$ in an icecold ultrasonic bath. This procedure was repeated twice. Pellets were lyophylised under $\mathrm{N}_{2}$. The collected pellets were resuspended in $1 \mathrm{ml}$ protein sample buffer (8 M urea, $2 \mathrm{M}$ thiourea, $0.5 \%$ pharmalyte buffer (v/v, pH 3-10); 4\% CHAPS; 30 mM DTT; 20 mM Tris-base, pH 8.8; 5 mM Pefablock). For solubilisation of proteins, samples were incubated for $2 \mathrm{~h}$ at $33^{\circ} \mathrm{C}$ and for $15 \mathrm{~min}$ in an ice-cold ultrasonic bath. After vortexing, samples were centrifuged (18000 g, 30 minutes) and the supernatant was subjected to isoelectric focusing (IEF). Protein concentration was determined in 1:50 dilutions of the samples according to the $2 \mathrm{D}$ QUANT protein determination kit from Amersham Biosciences.

Two-dimensional gel electrophoresis was done following the method described by Zörb et al. (2004). IPG strips (11 cm, pH 3-10, Amersham Biosciences) were placed in the trays and $200 \mu \mathrm{l}$ of the protein solution (150 $\mu$ g protein) were applied. Strips were covered with paraffin oil. IEF was carried out in a IPGphor chamber (Amersham Biosciences) applying the following conditions: 10 h rehydration; $100 \mathrm{~V}, 2$ h; $500 \mathrm{~V}, 1$ h; $1000 \mathrm{~V}, 2$ h; $8000 \mathrm{~V}, 2 \mathrm{~h}$. Temperature was $20^{\circ} \mathrm{C}$ and current was $45 \mu$ A per strip.

After running the first dimension, the strips were placed in equilibration buffer (50 mM TrisHCl, pH 8.8; 6 M urea; 30\% glycerol; 2\% (w/v) SDS; bromophenol blue, $0.001 \%(\mathrm{w} / \mathrm{v})$ containing $1 \%$ DTT (w/v)) and carefully shaken for $15 \mathrm{~min}$. Thereafter, the strips were incubated for additional 15 minutes in equilibration buffer with $4 \%$ (w/v) iodoacetamide without DTT under slow agitation. The strips were then rinsed with SDS-PAGE running buffer (25 mM Tris-base; $192 \mathrm{mM}$ glycine; $0.1 \%$ (w/v) SDS) for 15 minutes.

The second dimension SDS gels contained $12.5 \%(\mathrm{v} / \mathrm{v})$ acrylamide. Molecular weight standards in a range from 10 to $220 \mathrm{kDa}$ were obtained from Invitrogen. The marker lane was positioned at the acidic side $(\mathrm{pH} 3)$ of the gel. Strips and marker dyes were mounted onto the gel surface and sealed with $1 \%(\mathrm{w} / \mathrm{v})$ agarose containing $0.001 \%(\mathrm{w} / \mathrm{v})$ bromophenol blue. The second dimension was run at $20^{\circ} \mathrm{C}$ and with a constant current of $45 \mathrm{~mA}$ per gel in a Hoefer (20 $\mathrm{cm}^{\prime} 20 \mathrm{~cm}$ ) vertical gel electrophoresis chamber. Electrophoresis was stopped when the bromophenol blue left the gel and thereafter the gels were fixed with $50 \%$ ethanol and $12 \%$ acetic acid.

Staining and computer analysis. Coomassie staining was done according to a hot-staining protocol with Coomassie R350 tablets (Westermeier and Naven, 2002). Gels were digitised by scanning on an image scanner (Amersham Biosciences) with 300 dpi and 16 bits per pixel. The Coomassie-stained gel replicates 
for each of the drought-stressed and nonstressed treatments were fused and subsequent spot quantification was performed using Delta2D software (version 3.3) (Decodon, Greifswald, Germany). Matching of protein/peptide spots was performed manually. The most interesting spots in terms of expression levels (up- or downregulated by at least the factor of 2 or newly appearing or disappearing) were displayed using the statistical tools option of the software.

Data analysis. Data were subjected to analysis of variance (ANOVA) using the statistical package MSTAT-C, developed by Michigan State University (MSTAT-C, 1989). Means of the significant treatments were separated using the least significant difference (LSD) at 5\% level.

\section{RESULTS AND DISCUSSION}

Seed yield and yield components. In both genotypes, drought stress imposed at early podfilling stage resulted in significant seed yield reduction (Table 1). Drought stress that lasted for $20 \mathrm{~d}$ resulted in 53 and $30 \%$ seed yield reductions in BrSp and SEA 15, respectively. The effect of drought on seed yield was primarily due to the significant reduction in number of seeds per plant (Table 1). The smaller numbers of seeds per plant under stress for BrSp (20 under drought vs. 41 under control) were ascribed to the significant decrease by about $26 \%$ in the numbers of pods per plant and ca. $28 \%$ reduction in numbers of seeds per pod. For SEA 15, however, the reduction in the number of seeds per plant was due mainly to ca. $25 \%$ less number of productive pods retained per plant.

SEA 15 had higher relative yield than with BrSp, at similar levels of drought stress (Table 1), implying that the former genotype was more drought resistant. The number of pods per plant, followed by seeds per pod were the most affected yield components under drought stress (Table 1 ). This is consistent with reports on other legumes including common bean (Leport et al., 2006). Drought-induced abortion of pods for BrSp and SEA 15 was approximately two-third and $50 \%$ of the initial pod set, respectively. In line with the suggestions of Daie (1996), the higher rate of pod abortion found for BrSp may be due to limited assimilate supply under drought conditions (Fig. 2).

\section{Assimilate availability and ABA accumulation.} Drought stress did not alter the sucrose concentration in the productive pods of the two bean genotypes (Fig. 1). On the other hand, productive pod hexose sugar concentration was suppressed due to drought for BrSp but not for SEA 15 (data not presented). When compared with the productive pods, sucrose concentrations in the aborted pods of BrSp were 16 - 36 and 23 $62 \%$ of that of the control and drought-stressed plants of the genotype, respectively (Fig. 1). Likewise, aborted pod sucrose concentrations for SEA 15 were only $10-23$ and $14-33 \%$ of the concentrations found in the productive pods of the non-stressed and drought-stressed plants of the genotype, respectively.

TABLE 1. Seed yield and yield components of two common bean genotypes 20 days after the commencement of drought stress atpod-filling stage

\begin{tabular}{llccccc}
\hline \multicolumn{2}{c}{ Treatment } & Pods $\left(\right.$ plant $\left.{ }^{-1}\right)$ & Seeds $\left(\right.$ pod $\left.^{-1}\right)$ & $\begin{array}{c}100-\text {-seed } \\
\text { weight }(\mathrm{g})\end{array}$ & $\begin{array}{c}\text { Seed yield } \\
\left(\mathrm{g} \mathrm{plant}^{-1}\right)\end{array}$ & $\begin{array}{c}\text { Harvest } \\
\text { index (\%) }\end{array}$ \\
\hline Br Sp & Control & 12.8 & 3.18 & 21.0 & 8.5 & 23.9 \\
& Stress & 9.3 & 2.29 & 18.4 & 3.9 & 16.9 \\
SEA15 & Control & 15.1 & 4.10 & 24.0 & 14.9 & 61.1 \\
& Stress & 11.3 & 3.59 & 25.7 & 10.4 & 58.2 \\
Mean & & 12.2 & 3.29 & 22.3 & 9.42 & 40.0 \\
LSD $_{0.05}$ & & 0.99 & 0.36 & 2.74 & 1.04 & 3.25 \\
\hline
\end{tabular}




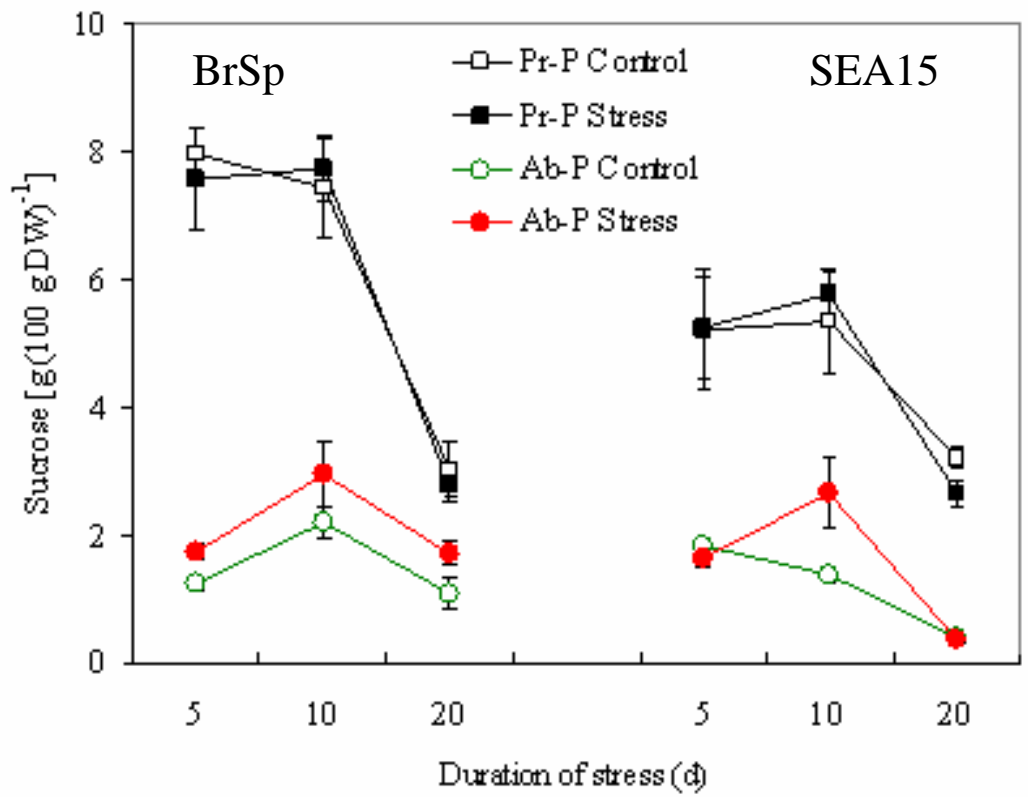

Figure 1. Productive pods ( $\mathrm{Pr}-\mathrm{P})$ and aborted pods $(\mathrm{Ab}-\mathrm{P})$ sucrose concentrations of two common bean genotypes grown under drought stress initiated at early pod-filling stage and non-stress growth conditions.

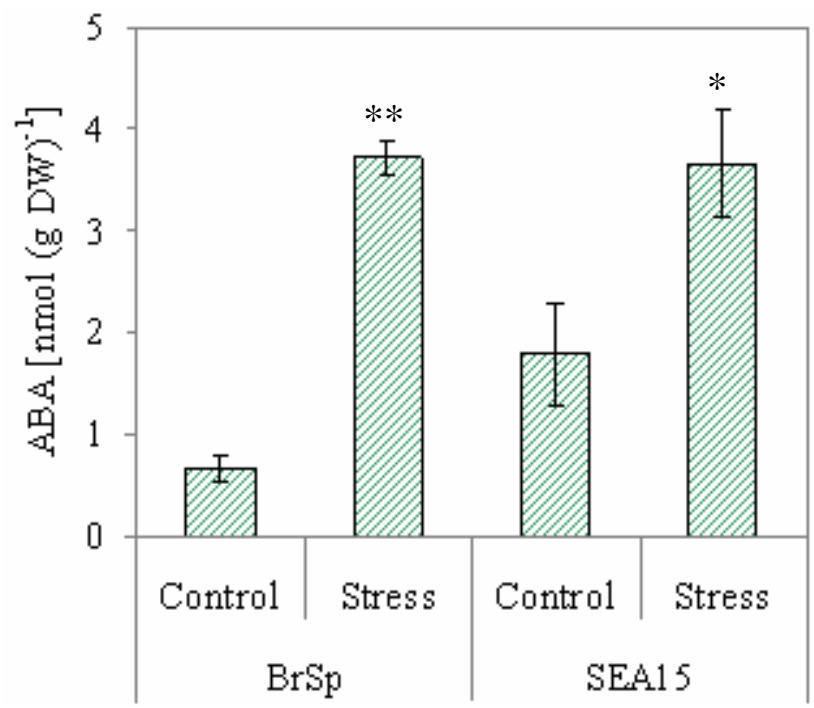

Figure 2. Effect of drought stress imposed during the vegetative phase on sink leaf abscisic acid (ABA) concentrations of two common bean genotypes. ","*Indicate significant differences between drought stressed and control treatments at 5 and $1 \%$ levels of probability, respectively, according to t-test.

In BrSp, similar levels of sucrose found in the pods of stressed plants with those grown under non-stress conditions could be due to the inhibition of the hydrolysis of incoming sucrose, because hexose sugar concentration in the same reproductive organ was significantly lowered under drought stress (data not presented). The failure to set reproductive sinks under drought stress in several grain crops is often associated with higher sucrose to hexose ratio caused by 
decreased invertase activities in the reproductive structures (Setter et al., 2001; Liu et al., 2004). In the above context, we suppose that in addition to sucrose availability, the capacity for utilising the assimilate may have been differently affected in the two bean genotypes under drought stress. The variation in sink strength (ability to metabolise imported sucrose by the pods) may, therefore, partly explain the observed genotypic difference in the establishment and growth of reproductive structures under drought conditions. As depicted in Figure 1, sucrose concentrations in aborted pods of the genotypes were 2-3 times lower than the concentrations in the corresponding productive pods under both soil moisture regimes. Therefore, it is possible that the underlying mechanisms controlling pod abortion in non-stressed bean plants are simply enhanced under drought stress.

Five days after the initiation of drought, both genotypes accumulated significantly large amounts of ABA in sink (expanding) leaves (Fig. 2). Relative to the corresponding non-stressed treatments, drought stress increased sink leaf ABA concentration of BrSp by ca. six-fold compared with only about two-fold for the drought-resistant genotype, SEA 15 (Fig. 2).

Drought-induced increase in ABA concentration of sink leaves (Fig. 2) was in line with previous reports on the accumulation of the plant hormone in young expanding leaves of other water-stressed plants (Alves and Setter, 2000). Despite comparable ABA accumulation in drought-stressed plants of the two genotypes, the increase was markedly higher for BrSp (drought-susceptible) than for SEA 15 (droughtresistant).

In soybean subjected to drought stress, flower and pod ABA concentration linearly correlated with xylem and leaf ABA concentrations, indicating that root-originated ABA and/or leaf ABA were the likely sources of ABA accumulated in the pods (Liu et al., 2003). Similarly, Nayyar et al. (2005) found that a droughtsusceptible chick pea cultivars that had higher rates of flower and pod abortion accumulated higher ABA than drought-tolerant ones, when subjected to drought stress. We suppose that sink leaf ABA correlates with pod ABA concentration. The differences in ABA accumulation due to drought relative to nonstress conditions (higher for BrSp compared with SEA 15) may partly explain the differences found in pod abortion between the two bean genotypes. Studies have shown that ABA accumulation in reproductive organs during early developmental inhibits cell division and subsequent abortion or failure to set seed (Wang et el., 2002).

\section{Carbohydrate import and utilisation in the seed.}

Varietal differences were found in terms of the level of sucrose available for metabolism in the seeds under drought stress conditions (Fig. 3). In BrSp, drought initiated at early pod-filling stage (5 d stress) caused ca. 29 to $47 \%$ (10 d stress) reduction in seed sucrose concentration relative to the non-stressed plants. On the contrary, seed sucrose concentrations for SEA 15 increased significantly by about 43 (at $10 \mathrm{~d}$ stress) and 19\% (20 d stress) as a consequence of the drought stress imposed during similar period.

Sucrose metabolism is pivotal in seed development and is particularly susceptible to drought stress (Pinheiro et al., 2005). The decrease in seed sucrose concentration due to drought at all durations of stress in $\mathrm{BrSp}$ (Fig. 3), reflected the lower availability of the assimilate at source level. A direct relationship between sucrose availability and export rate at source level and the establishment of new sink organs has been shown for several crops (Setter et al., 2001; Liu et al., 2004). In line with these reports, we suppose that the higher decrease in sink size (number of pods and seeds) of the droughtsusceptible genotype due to drought stress is partly attributed to reduced availability of the assimilate at source level (Ho, 1988).

Although a genotypic difference was evident for the length of the stress period at which the effects began to manifest, seed starch concentrations of both bean genotypes were decreased under drought stress (Fig. 4). Droughtinduced decrease in seed starch accumulation was more consistent across the stress period considered for BrSp than for SEA 15. In BrSp, drought stress at 5 and $20 \mathrm{~d}$ resulted in 16 and $18 \%$ less seed starch concentrations than the corresponding non-stressed plants (Fig. 4). On the other hand, drought stress that lasted up to 


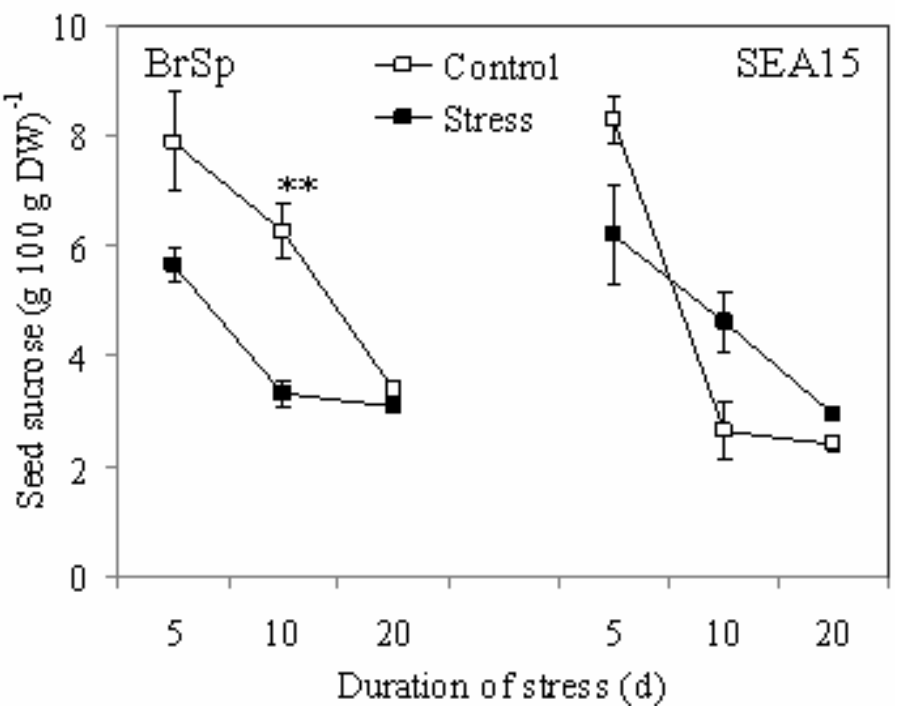

Figure 3. Effect of drought stress imposed at early pod-filling stage on seed sucrose concentrations of two common bean genotypes. " Indicate significant differences between drought stressed and control treatments at $1 \%$ levels of probability, respectively, according to t-test.

$10 \mathrm{~d}$ did not affect seed starch accumulation of the drought-resistant genotype, SEA 15 . When the stress period was prolonged to $20 \mathrm{~d}$, seed starch concentration of the genotype decreased by ca. $20 \%$ relative to the control treatment (Fig. 4).

Irrespective of the variation in sucrose availability in the seeds, drought-induced decrease in seed starch accumulation differed between the genotypes. The drought-induced decreases in seed starch concentration of $\mathrm{BrSp}$ were observed at all harvesting times ( 5 to $20 \mathrm{~d}$ stress) (Fig. 4) corresponding with seed sucrose levels measured during similar periods.

In wheat endosperm, Jenner et al. (1991) found a similar relationship between the two seed carbohydrates that the rate of storage starch accumulation was a function of the concentration of sucrose. Based on these relationships, it appears that shortage of assimilate (sucrose) could be one of the prime factors responsible for the reduced starch accumulation in the seeds of the drought-susceptible bean genotype. On the contrary, reduced seed starch concentration found in SEA 15 (only at $20 \mathrm{~d}$ stress) (Fig. 4) was not accompanied by a decrease in seed sucrose level, thus concurring with similar results reported for other crops (Brooks et al., 1982). These results imply that, apart from assimilate availability, drought stress may induce other factors that contribute to decreased seed starch synthesis. Limitations of sink activities due to the inhibition of the activities of key enzymes of sucrose metabolism, invertases and sucrose synthase (Weber et al., 2005), and starch synthesis (ADP-glucose pyrophosphorylase and starch synthase) (Ho, 1988) have been cited as principal factors responsible for reduced starch synthesis under drought situations.

Number and volume of cotyledonary cells, and amyloplasts. Drought stress affected neither the number nor the volume of cotyledonary cells per seed of the two common bean genotypes (Table 2). On the other hand, drought stress decreased the number of starch granules (amyloplasts) per seed, although the reductions were not significant for both genotypes (Table 2). The total estimated area of the starch granules decreased significantly due to drought stress (ca. $42 \%$ for BrSp vs. 33\% for SEA 15) compared with nonstresses plants of the genotypes.

By measuring the number of storage cells and the storage organelles within the sink, the physical constraint upon a sink organ's assimilate import and metabolism (sink size) can be 


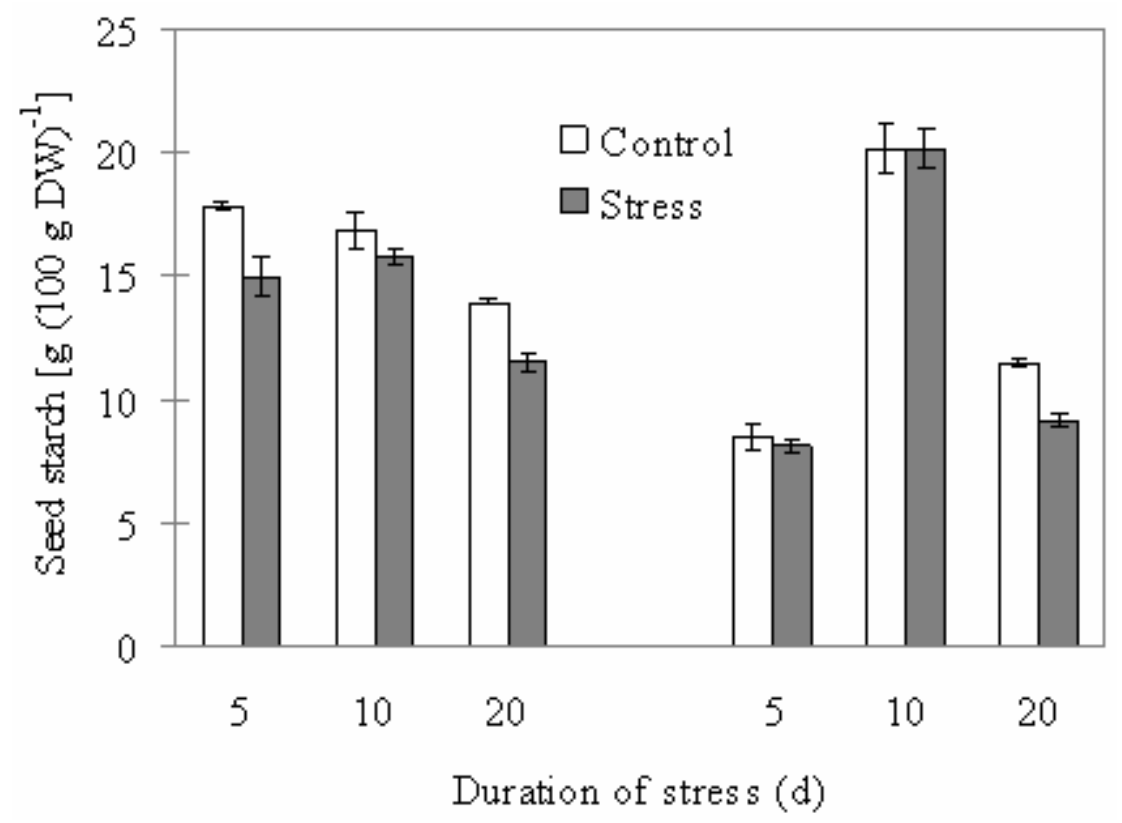

Figure 4. Effect of drought stress imposed at early pod-filling stage on seed starch concentrations of two common bean genotypes. *, * Indicate significant differences between drought stressed and control treatments at 5 and $1 \%$ levels of probability, respectively, according to t-test.

determined (Ho, 1988). Under both soil moisture regimes, SEA 15 had larger numbers of cotyledonary cells and amyloplasts per seed than BrSp (Table 2). The numbers and volume of cotyledonary cells were unaffected by drought stress for both genotypes (Table 2). Our findings are in agreement with the reports of Brooks et al. (1982), but deviate from that reported by Nicolas et al. (1985) for wheat plants subjected to low moisture stress during the reproductive growth. Drought stress caused a slight reduction in the number of amyloplasts per seed, but substantially decreased the area of the starch granules per seed for both genotypes (Table 2). Restriction of starch granule size expansion, therefore, appears to be the major limiting factor of seed starch accumulation under drought stress, attesting similar results reported for cassava (Santisopasri et al., 2001).

Leaf protein. A total of 550 different leaf proteins were detected by two-dimensional gel electrophoresis. Out of the proteins detected, 230 were differentially expressed due to a 10-day drought stress initiated during the vegetative phase (Table 3). The number of down-regulated proteins (23.5\% of total proteins detected) exceeded that of up-regulated ones (15.1\% of total proteins). Furthermore, stress induced the appearance of 10 new proteins, whereas 8 proteins disappeared compared with the non-stressed plants. Figure 5 shows the positions of these proteins from the leaves of drought- stressed BrSp.

The changes in leaf proteins of BrSp (Table 3 and Fig. 5) corroborate with previous reports on the responses of plants to drought stress (Riccardi et al., 1998; Salekdeh et al., 2002). Furthermore, the wide variation in sizes of the drought-responsive proteins detected was within the range reported for the dehydrin family of proteins (9 to $200 \mathrm{kDa}$ ) that are differentially expressed under dehydration stress (Close, 1996). Drought regulation of dehydrin gene expression was observed in both drought-tolerant and drought-susceptible cultivars (Cellier et al., 1998).

In the present study, the drought stressresponsive proteins were neither identified nor compared with stress- regulated proteins isolated from other plant species. However, recent identification and characterisation studies have demonstrated that most of the drought- 
TABLE 2. The effect of drought stress imposed at early pod-filling stage on the numbers and volumes of cotyledonary cells and amyloplasts of two common bean genotypes

\begin{tabular}{llllll}
\hline Treatment & & $\begin{array}{c}\text { Cotyledonary } \\
\text { cell seed } \\
\left(\times 10^{6}\right)\end{array}$ & $\begin{array}{c}\text { Volume } \\
\text { cotyledonary } \\
\text { cell }(\mathrm{nl})\left(\times 10^{-3}\right)\end{array}$ & $\begin{array}{c}\text { Amyloplasts } \\
\text { seed }^{-1} \\
\left(\times 10^{6}\right)\end{array}$ & $\begin{array}{c}\text { Circumference } \\
\text { of amylopasts } \\
\text { seed }^{-1}(\mu \mathrm{m}) \times 10^{7}\end{array}$ \\
\hline BrSp & Control & $0.99 \pm 0.08$ & $21.1 \pm 1.78$ & $11.3 \pm 0.77$ & $545.1 \pm 21.6$ \\
& Stress & $0.99 \pm 0.09$ & $20.4 \pm 1.94$ & $8.1 \pm 0.99$ & 316.247 .5 \\
SEA15 & Control & $1.59 \pm 0.11$ & $14.2 \pm 1.18$ & 16.61 .41 & $745.9 \pm 89.7$ \\
& Stress & $1.33 \pm 0.16$ & $20.0 \pm 2.92$ & 13.31 .40 & $400.5 \pm 40.8$ \\
& & & & & 501.9 \\
& Mean & 1.23 & 18.9 & 12.3 & 239.9 \\
\hline
\end{tabular}

Data are means \pm S.E. of four replications

TABLE 3. The effect of a $10 \mathrm{~d}$ drought stress on quantitative and qualitative changes in leaf proteins of common bean (cv. BrSp)

\begin{tabular}{lrr}
\hline Regulation & Number & \% of total \\
\hline Total proteins detected & 550 & 100.0 \\
Differentially expressed (total) & 230 & 41.8 \\
Newly appeared & 10 & 1.8 \\
Up-regulated & 83 & 15.1 \\
Down-regulated & 129 & 23.5 \\
Disappeared & 8 & 1.5 \\
\hline
\end{tabular}

responsive proteins are related to metabolism, energy, protein biosynthesis, cell defense, signal transduction, transport, and lignification (Salekdeh et al., 2002; Rodríguez et al., 2006). Also, evidences are unfolding in favor of a relationship between the accumulation of drought-induced proteins and physiological adaptation traits to water limitation (Riccardi et al., 1998).

\section{CONCLUSION}

Drought stress significantly but differentially affected the growth and yield of the two contrasting genotypes. The numbers of pods per plant followed by seeds per pod were the most affected yield components under drought stress. Compared with BrSp, SEA 15 had larger number of reproductive sinks (pods and seeds) and higher harvest index under drought stress. Similar pod sucrose concentration found between the contrasting watering regimes for both genotypes imply that instead of sucrose availability per se, the capacity for utilizing the assimilate may have been differentially affected under drought stress. The reduction in seed starch accumulation of the genotypes due to the stress imposed exhibited marked differences. The decrease in seed starch accumulation of BrSp corresponded with decreased availability of the substrate (sucrose) whereas the decrease found for SEA 15 could be due to the inhibition of sink activity factors rather than sucrose availability. Among the sink capacity factors considered, drought-induced restriction on starch granule size expansion appears to be the major limiting factor for the observed reduced seed starch accumulation of the bean genotypes. Drought-responsive proteins of wide variation in size (within the range reported for the dehydrin family of proteins) were detected. These proteins are known to play significant role in physiological adaptation (metabolism, energy, protein biosynthesis, cell defense, signal transduction, transport, and lignifications) of the crop to drought situations.

\section{ACKNOWLEDGMENT}

The authors dully acknowledge the financial support provided by the German Academic Exchange Service (DAAD). 
MW

(KDa) 3

IEF

10
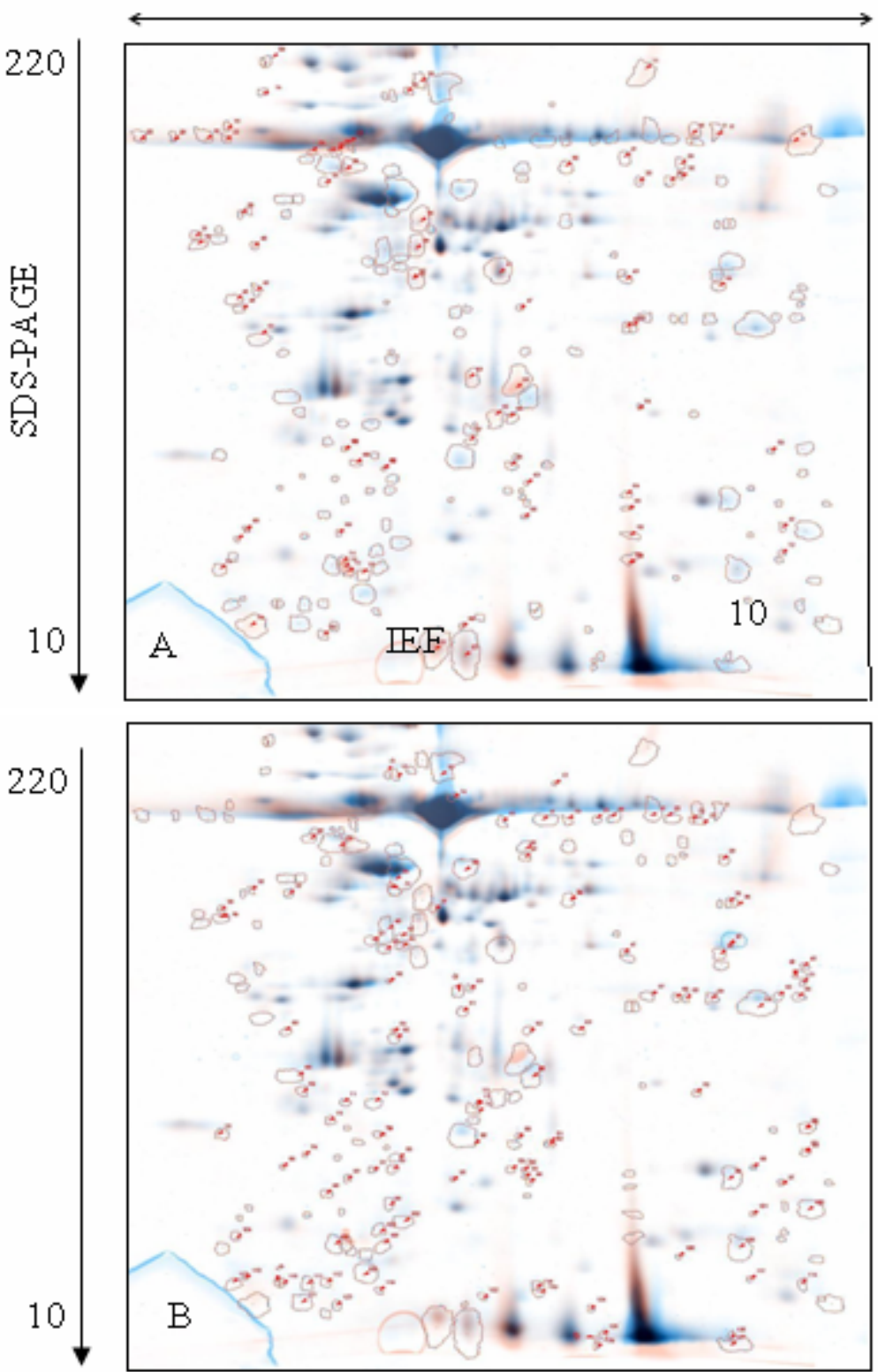

Figure 5. Coomassie-stained 2D gel of total proteins extracted from mature leaves of drought-stressed cv. BrSp. The proteins were separated by two-dimensional isoelectric focusing (IEF)/ SDS-polyacrylamide gel electrophoresis (SDS-PAGE). Locations of the drought stress-responsive proteins (spots) are marked by circular boundaries. The arrows indicate 83 up-regulated proteins (A) and 129 down-regulated proteins (B) in drought-stressed plants in relation to non-stressed plants. 


\section{REFERENCES}

Alves, A.A.C. and Setter, T.L. 2000. Response of cassava to water deficit: Leaf area growth and abscisic acid. Crop Science 40:131-137.

Brooks, A., Jenner, C. F. and Aspinall, D. 1982. Effects of water deficit on endosperm starch granules and on grain physiology of wheat and barley. Australian Journal of Plant Physiology 9:23-436.

Cellier, F., Conejero, G., Breitler, J.C. and Casse, F. 1998. Molecular and physiological responses to water deficit in drought-tolerant and drought-sensitive lines of sunflower. Plant Physiology 116:319-328.

CIAT (Centro International Agriculture de Tropical). 2002. Bean Annual Report. Cali, Columbia. pp. 96.

Close, T.J. 1996. Dehydrins: emergence of a biochemical role of a family of plant dehydration proteins. Physiological Plantarum 100:291-296.

Daie, J. 1996. Metabolic adjustments, assimilate partitioning, and alterations in source-sink relations in drought-stressed plants. In: Zamski, E. and Schaffer, A. (Eds.), pp. 407420. Photoassimilate Distribution in Plants and Crops. Marcel Dekker, Inc. New York.

Gebeyehu, S., Wiese, H. and Schubert, S. 2006. Physiological response to drought stress of common bean genotypes subjected to drought stress. PhD Diss. Justus Liebig University of Giessen, Germany. pp. 128.

Ho, L.C. 1988. Metabolism and compartmentation of imported sugars in sink organs in relation to sink strength. Annual Review of Plant Physiology and Mol Biology 39:355-378.

Ingram, J. and Bartels, D. 1996. The molecular basis of dehydration tolerance in plants. Ann. Rev. Plant Physiol. Plant Molecular Biology 47:377-403

Ishitani, M., Nakamura, T., Han, S.Y. and Takabe, T. 1995. Expression of the betaine aldehyde dehydrogenase gene in barley in response to osmotic stress and abscisic acid. Plant Molecular Biology 27:307-315.

Jenner, C.F., Uglade, T.D. and Aspinall, D. 1991. The physiology of starch and protein deposition in the endosperm of wheat.
Australian Journal of Plant Physiology 18: 211-226.

Kim, J.Y., Mahé, A., Brangeon, J. and Prioul, J.L. 2000. A maize vacuolar invertase, IVR2, is induced by water stress. Organ/tissue specificity and diurnal modulation of expression. Plant Physiology 124:71-84.

Koç, M., Barutçular, C. and Genç, I. 2003. Photosynthesis and productivity of old and modern durum wheats in a Mediterranean environment. Crop Science 43:2089-2098.

Leport, L., Turner, N.C., Davies, S.L. and Siddique, K.H.M. 2006. Variation in pod production and abortion among chickpea cultivars under terminal drought. European Journal of Agronomy 24 (3):236-246.

Lisse, T., Bartels, D., Kalbitzer, H.R. and Jaenicke, R. 1996. The recombinant dehydrin-like desiccation stress protein from the resurrection plant Craterostigma plantagineum displays no defined threedimensional structure in its native state. Biological Chemistry 377:555 -561.

Liu, F., Jensen, C.R. and Andersen, M. N. 2004. Drought stress effect on carbohydrate concentration in soybean leaves and pods during early reproductive development: it s implication in altering pod set. Field Crops Research 86(1):1-13.

Liu, F., Andersen, M.N. and Jensen, C.R. 2003. Loss of pod set caused by drought stress is associated with water status and ABA content of reproductive structures in soybean. Functional Plant Biology 30: 271-280.

Mertens, R.J., Deus-Neumann, B. and Weiler, E.W. 1985. Monoclonal antibodies for the detection and quantification of the endogenous plant growth regulator, abscisic acid. FEBS Letters 160:269-272.

MSTAT-C. 1989. MSTATC-C, a microcomputer program for the design, management, and analysis of agronomic research experiments. Michigan State Univ., East Lansing, MI.

Nayyar, H., Kaur, S., Smita, K., Singh, J., Dhir, K. K. and Bains, T. 2005. Water stress-induced injury to reproductive phase in chickpea: evaluation of stress sensitivity in wild and cultivated species in relation to abscisic acid and polyamines. Journal of Agronomy Crop Science 191:450-457. 
Neslihan-Ozturk, Z., Talame1,V., Deyholos, M., Michalowski, C.B., Galbraith, D.W., Gozukirmizi, N., Tuberosa, R. and Bohnert, H. J. 2002. Monitoring large-scale changes in transcript abundance in drought- and saltstressed barley. Plant Molecular Biology 48: 551-573.

Pinheiro, C., Rodrigues, A.P., de Carvalho, I.S., Chaves, M.M. and Ricardo, C.P. 2005. Sugar metabolism in developing lupin seeds is affected by a short-term water deficit. Journal Experimental Botany 56(420):2705-2712.

Ramirez-Vallejo, P. and Kelly, J.M. 1998. Traits related to drought resistance in common bean. Euphytica 99:127-136.

Riccardi, F., Gazeau, P. de Vienne, D. and Zivy, M. 1998. Protein changes in response to progressive water deficit in maize. Quantitative variation and polypeptide identification. Plant Physiology 117:12531263.

Salekdeh, G.H., Siopongco, J., Wade, L.J., Ghareyazie, B. and Bennett, J. 2002. Proteomic analysis of rice leaves during drought stress and recovery. Proteomics 2(9):1131-45

Santisopasri, V., Kurotjanawong, K., Chotineeranat, S., Piyachomkwan, K., Sriroth, K. and Oates, C.G. 2001. Impact of water stress on yield and quality of cassava starch. Industrial Crops Production 13:115-129.
Setter, T.L., Flannigan, B.A. and Melkonian, J. 2001. Loss of kernel set due to water deficit and shade in maize: carbohydrate supplies, abscisic acid, and cytokinins. Crop Science 41:1530-1540.

Singh, S.P. 2001. Broadening the genetic base of common bean cultivars. Crop Science 4:16591675.

Terán, H. and Singh, S. 2002. Comparison of sources and lines selected for drought resistance in common bean. Crop Science 42: 64-70.

Weber, H., Borisjuk, L. and Wobus, U. 2005. Molecular physiology of legume seed development. Annual Review of Plant Biology 56:253-279.

Wessel-Beaver, L., Beck, R. H. and Lambert, R. J. 1984. Rapid method for measuring kernel density. Agronomy Journal 76:307-309.

Westermeier, R. and Naven, T. 2002. Proteomics in Practice, A laboratory manual of proteome analysis, Amersham Pharmacia Biotech, Wiley-VHC, Little Chalfont, UK

Zörb, C., Schmitt, S., Neeb, A., Karl, S., Linder, M. and Schubert, S. 2004. The biochemical reaction of maize (Zea mays L.) to salt stress is characterized by a mitigation of symptoms and not by a specific adaptation. Plant Science 167:91-100. 